\title{
INITIAL GROWTH OF SEEDLINGS OF Eucalyptus dunnii Maiden AS INFLUENCED BY THE ADDITION OF NATURAL POLYMER AND FARMING SUBSTRATES ${ }^{1}$
}

\author{
Marcio Carlos Navroski ${ }^{2 *}$, Maristela Machado Araujo ${ }^{3}$, Lia Rejane Silveira Reiniger ${ }^{4}$, Claudimar Sidnei \\ Fior $^{5}$, Gilmar Schafer ${ }^{5}$ and Mariane de Oliveira Pereira ${ }^{6}$
}

\footnotetext{
${ }^{1}$ Received on 22.10.2013 accepted for publication on 30.06.2016.

${ }^{2}$ Universidade do Estado de Santa Catarina, Departamento de Engenharia Florestal, Lages, SC - Brasil. E-mail: $<$ marcio.navroski@udesc.br>.

${ }^{3}$ Universidade Federal de Santa Maria, Departamento de Ciências Florestais, Santa Maria, RS - Brasil. E-mail:

$<$ araujo.maristela@gmail.com>.

${ }^{4}$ Universidade Federal de Santa Maria, Centro de Ciências Rurais, Departamento de Fitotecnia, Santa Maria, RS - Brasil. E-mail: <liarejanesilveirareiniger@yahoo.com.br>.

${ }^{5}$ Universidade Federal do Rio Grande do Sul, Faculdade de Agronomia, Porto Alegre, RS - Brasil. E-mail: <csfior@ufrgs.br> and <schafer@ufrgs.br>.

${ }^{6}$ Universidade Federal do Paraná, Programa de Pós-graduação em Engenharia Florestal, Curitiba, PR - Brasil. E-mail: $<$ maripereira.florestal@gmail.com>.

*Corresponding author.
}

\begin{abstract}
This study aimed to test different concentrations of natural polymer combined with different substrates in order to maximize the production and quality of Eucalyptus dunnii Maiden as well as the influence of the physical and chemical properties of the substrates. Experiments were conducted in a greenhouse in a randomized design with a 4 × 4 factorial arrangement for different substrates (factor " $\mathrm{A}$ ") and water-retaining polymer concentrations (factor "B"). The physical and chemical properties of the substrates were also analyzed in each treatment. The seedlings height (H), neck diameter (D), shoot dry matter (SDM), root dry matter (RDM), total dry matter (TDM), H/D ratio and Dickson quality index (DQI) were measured after 90 days of sowing. Both the physical and chemical properties of the substrates have improved by the addition of hydrogel, especially those regarding to porosity, water availability and water holding capacity. In general, the water-retaining polymer concentrations of 2 and $4 \mathrm{~g} \mathrm{~L}^{-1}$ provided a better seedling growth. Seedlings largest neck diameter was observed at a hydrogel concentration of $6 \mathrm{~g} \mathrm{~L}^{-1}$. The use of hydrogel has resulted in higher height and neck diameter values when carbonized rice hulls were used as substrate. Therefore, hydrogel concentrations of 2 and $4 \mathrm{~g} \mathrm{~L}^{-1}$ may increase the quality of Eucalyptus dunnii seedlings and reduce their nursery time.
\end{abstract}

Keywords: Seedling production; Water holding capacity; Hydrogel.

\section{CRESCIMENTO INICIAL DE MUDAS DE Eucalyptus dunnii Maiden COM UTILIZAÇÃO DE POLÍMERO NATURAL E SUBSTRATOS DE CULTIVO}

RESUMO-O objetivo deste estudo foi testar diferentes doses do polímero à base de amido de milho combinado com diferentes substratos, visando à maximização da produção e qualidade de mudas de Eucalyptus dunnii Maiden e a influência das características físicas e químicas dos substratos. O experimento foi conduzido em casa de vegetação, utilizando delineamento inteiramente casualizado em arranjo fatorial $4 x 4$, em que os niveis do fator " $A$ " referiram-se aos diferentes subtratos e os níveis do fator " $B$ " às doses do hidroretentor. Para cada tratamento realizou-se análise fisica e química do substrato. Após 90 dias da semeadura avaliouse a altura, diâmetro do colo, MMSPA, MMSR, MMST e o cálculo da relação h/dc e do IQD. A adição do hidrogel melhorou as características fisicas e químicas dos substratos, principalmente às relacionadas com porosidade, disponibilidade de água e capacidade de retenção de água. As dosagens de 2 e $4 \mathrm{~g} L-1$ do hidroretentor proporcionaram melhor crescimento das mudas. O maior diâmetro de coleto foi observado 
com a dose de $6 \mathrm{~g} \mathrm{~L}^{-1}$ do hidrogel. Quando a casca de arroz carbonizada foi utilizada, o uso do hidrogel proporcionou elevação da altura e diâmetro de coleto. Assim, o hidrogel, em dosagens entre 2 e $4 \mathrm{~g} \mathrm{~L}^{-1}$ pode melhorar a qualidade das mudas de Eucalyptus dunnii diminuindo o tempo de permanência no viveiro.

Palavras-chave: Mudas; Retenção de água; Hidrogel.

\section{INTRODUCTION}

For meeting the constantly expanding demand for forest products it is necessary to establish new plantations, which, in order to be profitable, must have a high productivity rate and allow a relatively short cutting cycle associated with the products' quality and sustainability. Thus, when considering the installation of forest stands, the quality of the seedling should be prioritized as it has direct impact on the productivity as well as on the quality of the final product (CALDEIRA et al., 2007).

In addition to the substrate, fertilizing and watering are considered to be the main factors related to forest seedlings production costs. In order to reduce nutrients and watering costs, therefore increasing environmental benefits due to lower water consumption and nutrient leaching, the use of water-retaining gels, also known as hydrogels or water-retaining polymers, have been studied in recent years (BERNARDI et al., 2012).

Water-retaining polymers have been marketed under the excuse that, when incorporated into the substrate, they allow a higher retention of water and fertilizers, which can be slowly released to plants due to absorption-release cycles. Moreover, their high cation exchange capacity (CEC) reduces the leaching of nutrients (TAYLOR; HALFACRE, 1986).

Owing to such properties, water-retaining gels have been used to improve the plants' moisture condition. However, there is a lack of scientific information on the effects of adding these polymers into substrates used for producing seedlings in test tubes as well as on their physical and chemical properties associated with different substrates.

Hence, this study aimed to test the concentration of a corn starch-based water-retaining polymer combined with different substrates in order to maximize the production and quality of Eucalyptus dunnii Maiden seedlings.

\section{MATERIALS AND METHODS}

Experiments were conducted in a greenhouse of the forest nursery belonging to the Department of Forest

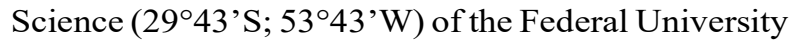

of Santa Maria, Brazil, between March and June 2012. According to Köppen climate classification, such region is a "Cfa" type zone (MORENO, 1961). Average temperature and relative air humidity during the experiments period were $18.0^{\circ} \mathrm{C}$ and $79.4 \%$, respectively (INMET, 2013).

Substrates were composed by the following volume ratio mixtures: 1) commercial substrate Carolina Soil ${ }^{\circledR}$ (COM); 2) commercial + average particle size expanded vermiculite $(\mathrm{COM}+\mathrm{EV})(1: 1) ; 3)$ commercial + carbonized rice hull $(1: 1)(\mathrm{COM}+\mathrm{CRH})$; and 4$)$ commercial + average particle size expanded vermiculite + carbonized rice hull $(1: 1: 1)(\mathrm{COM}+\mathrm{EV}+\mathrm{CRH})$. Experiments were carried out with six repetitions so that each portion consisted of 24 plants. Only the eight central plants of each portion were then considered for the analysis.

According to its manufacturer, the commercial substrate Carolina Soil $\AA$ is composed of sphagnum peat, expanded vermiculite, dolomitic limestone, agricultural gypsum and NPK fertilizer. Different concentrations of the natural starch-based hydro polymer Zeba ${ }^{\circledR}$ were incorporated to the substrates before filling the containers (at concentrations of 0 ; 2; 4 and $\left.6 \mathrm{~g} \mathrm{~L}^{-1}\right)$. Experiments were conducted in a completely randomized design with a $4 \times 4$ factorial arrangement where the "A" factor corresponds to the substrates whereas the " $B$ " factor refers to the water-retaining polymer concentration.

Test tubes with a volume of $110 \mathrm{~cm}^{3}$ were used as containers. The hydro polymer was added to the substrates according to treatment, as well as a controlled-release fertilizer (18:5:9 NPK) at $6 \mathrm{~g} \mathrm{~L}^{-1}$ of substrate concentration, as recommended by Bernardi et al. (2012). According to the manufacturer, the nutrients' release time varies from 4 to 6 months. For a homogeneous mixture of polymer and fertilizer it was used 5 liters of substrate for each mixture.

After mixing, the test tubes were filled according to each treatment, arranged in trays and subjected to the vibrating table for about 10 seconds. In order to prevent the leakage of the substrate due to the 
expansion of hydro polymer particles during hydration, only about $80 \%$ of the tubes' maximum volume was filled.

Sowing was carried out by placing two or three seeds in each container and covering them with a thin layer of fine vermiculite. After sowing, the test tube trays were taken to a greenhouse for 90 days until the evaluation of the experiment. After 40 days of sowing, it occurred the thinning out of seedlings, remaining only the strongest grower in the center of each container. After 60 days of sowing, the seedlings density decreased in $50 \%$ (from the initial density of 400 plants per $\mathrm{m} 2$ to 200 plants per $\mathrm{m} 2$ ). Watering was carried out by a watering bar composed of $4 \mathrm{~mm}$ micro sprinklers activated by a timer four times a day: at $8 \mathrm{am}, 11 \mathrm{am}, 2 \mathrm{pm}$ and $5 \mathrm{pm}$.

After 90 days of sowing, the experiment was finally evaluated by the following parameters: total height (from the seedling's neck to its apical stem) (H); neck diameter (D); shoot dry matter (SDM); root dry matter (RDM); and total dry matter (TDM). The Dickson Quality Index (DQI) was therefore calculated based on the values of H, D, RDM and SDM, which is given by the sum of the dry matter of the leaves and the neck, through the following formula (DICKSON et al., 1960):

$$
\mathrm{DQI}=\frac{\mathrm{TDM}(\mathrm{g})}{\frac{\mathrm{H}(\mathrm{cm})}{\mathrm{D}(\mathrm{mm})}+\frac{\mathrm{SDM}(\mathrm{g})}{\mathrm{RDM}(\mathrm{g})}}
$$

In order to obtain the dry matter the seedlings were separated into shoot and root. The root system containing substrate was then washed under running water and the roots were separated through a sieve. Both the shoot and the roots were later dried in a hothouse at $70^{\circ} \mathrm{C}$ until constant weight $(72 \mathrm{~h})$. After that, they were measured on a precision scale.

The physical and chemical properties of the substrates with their respective mixtures of hydro polymer were analyzed in the Substrates Laboratory of the Department of Horticulture and Forestry, Federal University of Rio Grande do Sul, in accordance with the $17^{\text {a }}$ normative instruction of the Ministry of Agriculture, Livestock and Food Supply (BRASIL, 2007) as well as according to Fermino (2003).

Among the physical properties related to the density and moisture of the substrate we have considered the wet density - WD $\left(\mathrm{kg} \mathrm{m}^{-3}\right)$; the dry density - DD $\left(\mathrm{kg} \mathrm{m}^{-3}\right)$; and the percent moisture $\mathrm{M}(\%)$. Pressure funnels of $0,-10,-50$ and $-100 \mathrm{hPa}$ were used for determining both the aeration space and the available water (FERMINO, 2003). Therefore it was possible to calculate the total porosity (TP); aeration space (AS); readily available water (RAW); water buffering capacity (WBC); available water (AW); soil water retention (SWR 100); and water holding capacity (WHC) in different pressures

As far as chemical properties are concerned, the electric conductivity and the $\mathrm{pH}$ were analyzed through a conductivimeter and a potentiometer ( $\mathrm{pHmeter),}$ respectively. A dilution of 1:5(v/v) with deionized water was applied in both cases.

Also, the $\mathrm{pH}$, electric conductivity and total soluble salts (TSS) of washed sand samples containing hydrogel were analyzed so as to serve as parameter. Both the $\mathrm{pH}$ and the electric conductivity of samples were determined by the same means as the $\mathrm{pH}$ and the electric conductivity of substrates. Yet the total soluble salts (TSS) of samples were determined through calculation, by considering the $\mathrm{EC}\left(\mathrm{mS} \mathrm{cm}^{-1}\right)$ as well as the density of the material, in suspension sand: deionized water ratio of $1: 10(\mathrm{~m} / \mathrm{v})$, expressed as $\mathrm{KCl}$ content (RÖBER; SCHALLER, 1985).

All data obtained were subjected to the analysis of variance. The breakdown of interactions was held as needed. Means were compared by the Scott-Knott test and/or the polynomial regression analysis with a level of probability set at 0.05 . The point of maximum technical efficiency (MTE) was thus determined for quadratic equations in case of significant effect. Analyses were carried out by the means of the SISVAR statistical package (FERREIRA, 2011).

\section{RESULTS}

The analysis of variance showed a significant effect $(p<0.001)$ for the factors substrate $\mathrm{x}$ hydrogel concentration as far as the soil water retention (SWR) and water holding capacity (WHC10, WRC50 and WHC100) are concerned. Regarding other physical properties an interaction between the tested factors $(p<0.05)$ has been observed.

Total porosity (TP) has risen for all substrates as the hydrogel concentration increased (Figure 1A). With no hydrogel added, the commercial substrate

Revista Árvore, Viçosa-MG, v.40, n.4, p.627-637, 2016

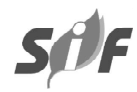


with the carbonized rice hull $(\mathrm{COM}+\mathrm{CRH})$ has shown the highest TP, keeping this tendency with the addition of the polymer. The opposite behavior was observed for the aeration space (AS), which has lowered as the concentration of hydrogel added to the substrate increased (Figure 1B). Substrates with carbonized rice hull have shown a higher percent of AS when compared to others, however, it has lowered as the concentration of hydrogel increased.

The readily available water (RAW) variable has shown a similar behavior (Figure 1C), varying according to the hydrogel concentration and the mixture that composed the substrate. It has risen for the commercial substrate (COM) and the commercial substrate with carbonized rice hull (CRH) as the concentration of the hydro polymer increased. Yet for the commercial substrate with vermiculite $(\mathrm{COM}+\mathrm{EV})$ and the mixture of all three $(\mathrm{COM}+\mathrm{EV}+\mathrm{CRH})$ it has not been influenced by the presence of hydrogel, either remaining stable or even slightly lowering as higher concentrations of the polymer were added.

A change of behavior according to the mixture of the substrate and the addition of hydro polymer was observed in the water buffering capacity (WBC) (Figure 1D). It has risen for the commercial substrate as the hydro polymer concentration increased; however, it has become either stable or low for the mixtures with vermiculite and/or carbonized rice hull. Regarding the substrate composition, the highest percent of SWR was obtained in the treatment COM+EV (52.25\%), standing out from the other treatments which have reached values from 30.45 up to $39.87 \%$.
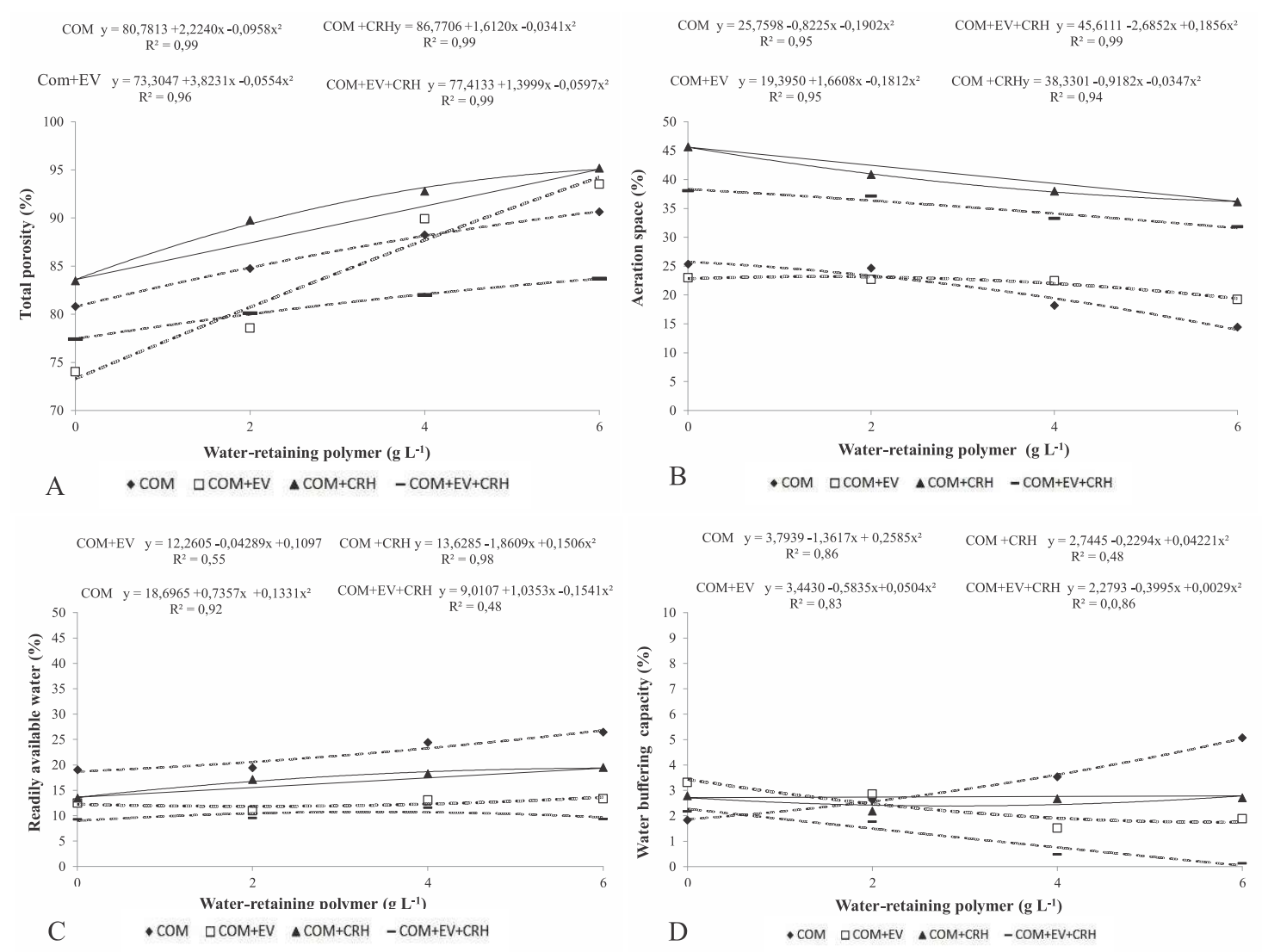

Figure 1 - A- Total porosity (\%); B - Aeration space (\%), C - Readily available water (\%) and D - Water buffering capacity $(\%)$ for different substrate compositions and hydro polymer concentrations in the production of $E$. dunnii seedlings.

Figura 1-A-Porosidade total (\%); B - Espaço de aeração (\%); C-Água facilmente disponivel (\%) e D-Água tamponante (\%) em função de diferentes composições do substrato e dosagens do polímero hidroretentor na produção de mudas de E. dunnii.

Revista Árvore, Viçosa-MG, v.40, n.4, p.627-637, 2016 
At a pressure of $10 \mathrm{hPa}$ the commercial substrate has shown the highest WHC percent (65.48\%) followed by the substrate COM+EV (60.16\%). The substrate $\mathrm{COM}+\mathrm{CRH}$ has shown an intermediate WHC (50.14\%) while the mixture of all three compounds has shown the lowest WHC percent at $10 \mathrm{hPa}(45.71 \%)$. By applying higher pressures (from 50 to $100 \mathrm{hPa}$ ) the highest water holding capacity value was obtained with the substrate $\mathrm{COM}+\mathrm{EV}$, standing out from the other substrates which have reached values of $49.65 \%$ and $39.87 \%$, respectively.

The water holding capacity has increased in the presence of higher concentrations of hydrogel and decreased with lower amounts of the polymer (Figure 2).

Equations have changed little for the chemical properties of electric conductivity (EC) and $\mathrm{pH}$ in spite of having interaction between the factors tested by the analysis of variance (Table 1). In general, the EC has risen with higher concentrations of the hydro polymer so that its greater variation occurred with the substrate obtained from the mixture of all three components $(\mathrm{COM}+\mathrm{EV}+\mathrm{CRH})$ where it has practically doubled at a concentration of $6 \mathrm{~g} \mathrm{~L}^{-1}$ as compared to the absence of hydrogel. Among substrates, the commercial has shown the highest EC values regardless the presence of hydrogel or tested concentrations. Regarding the chemical properties of the washed sand (inert material) adding the natural polymer has caused the increase of electric conductivity, $\mathrm{pH}$ and total soluble salts (TSS) (Table 1).

The analysis of variance has shown interaction between the isolated factors for the variable height $(p<0.001)$ and neck diameter $(p<0.001)$ regarding the

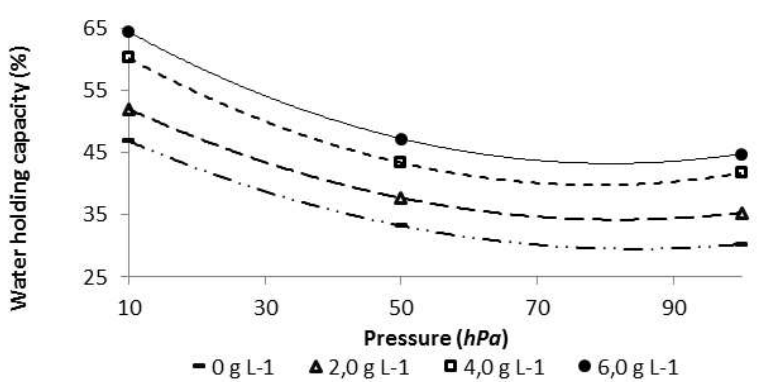

Figure 2 - Water holding capacity of substrates at 10,50 and $100 \mathrm{hPa}$ by using different concentrations of hydrogel.

Figura 2 - Curva característica de retenção de água dos substratos submetidos às tensões 10, 50 e 100 hPa utilizando-se diferentes dosagens do hidrogel. seedlings' initial growth. In relation to height/neck diameter ratio (H/D) a significant effect was observed only for the substrate factor $(p<0.001)$, just as for the following variables: root dry matter $-\operatorname{RDM}(p=0.042)$ and total dry matter $-\mathrm{TDM}(p=0.048)$. For the variable shoot dry matter (SDM) significant effects were observed for both isolated factors: substrate $(\mathrm{p}=0.027)$ and waterretaining polymer concentration $(p=0.038)$. The Dickson quality index (DQI) has shown a significant effect only for the polymer concentration $(p=0.045)$.

By using the COM substrate it was possible to observe the highest height of seedlings at a hydrogel concentration of $1.58 \mathrm{~g} \mathrm{~L}^{-1}$ (Figure $3 \mathrm{~A}$ ). Seedlings neck diameter (D) has enlarged as the hydrogel concentration increased, regardless the substrate used (Figure 3B). Failure to use the hydro polymer has resulted in lower height and neck diameter as compared to other treatments. According to the quadratic regression equation, the highest increase in seedling height by using the substrate $\mathrm{COM}+\mathrm{CRH}$ was observed at a natural polymer concentration of $3.86 \mathrm{~g} \mathrm{~L}^{-1}$. However, at a concentration of $6 \mathrm{~g} \mathrm{~L}^{-1}$ a reduction in seedling height was observed. Failure to use the hydro polymer in this type of substrate has resulted in smaller seedlings.

By using the substrate COM+EV the highest seedling height was reached at a hydrogel concentration of 2.01 $\mathrm{g} \mathrm{L}^{-1}$, as shown in the quadratic equation (Figure $3 \mathrm{~A}$ ). At the highest hydrogel concentration $\left(6 \mathrm{~g} \mathrm{~L}^{-1}\right)$ the seedlings have shown the lowest height even when compared to the treatment without hydro polymer. According to the regression equation, hydrogel at a concentration of $3.18 \mathrm{~g} \mathrm{~L}^{-1}$ has caused the highest $E$. dunnii seedling height mean with the mixture of all three components as substrate (Figure 3A). Therefore, increased hydrogel concentrations showed a tendency to decrease the seedlings height. Failure to use the hydro polymer in this case has also caused the formation of smaller seedlings.

The highest H/D ratio was obtained with the substrates COM+EV (10.95) and COM+CRH (10.94), standing out from other substrates. The highest SDM was obtained by using as substrate the COM+EV $(2.50 \mathrm{~g})$ and the mixture of all three components $(2.12 \mathrm{~g})$, standing out from other treatments. The highest RDM mean was obtained from the substrate mixtures COM+EV $(0.90 \mathrm{~g})$ and $\mathrm{COM}+\mathrm{CRH}(0.93 \mathrm{~g})$. Seedlings with the lowest root dry matter $(0.65 \mathrm{~g})$ were obtained by using the commercial substrate. TDM has shown similar results so that the

Revista Árvore, Viçosa-MG, v.40, n.4, p.627-637, 2016

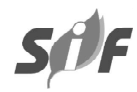


Table 1 - Determination of chemical properties on substrates containing different concentrations of the hydro polymer used for E. dunnii seedlings production.

Tabela 1 - Determinação de características químicas em substratos contendo diferentes dosagens do polímero hidroretentor utilizados na produção de mudas de E. dunnii.

\begin{tabular}{|c|c|c|c|c|c|}
\hline \multirow[t]{2}{*}{ Determination } & \multirow[t]{2}{*}{ Substrate } & \multicolumn{4}{|c|}{ Hydro polymer concentration $\left(\mathrm{g} \mathrm{L}^{-1}\right)$} \\
\hline & & 0 & 2 & 4 & 6 \\
\hline \multirow[t]{4}{*}{$\mathrm{EC}\left(\mathrm{mS} \mathrm{cm}^{-1}\right)$} & $\mathrm{COM}^{*}$ & 0,46 & 0,39 & 0,45 & 0,49 \\
\hline & $\mathrm{COM}+\mathrm{EV}$ & 0,19 & 0,21 & 0,20 & 0,25 \\
\hline & $\mathrm{COM}+\mathrm{CRH}$ & 0,24 & 0,30 & 0,30 & 0,33 \\
\hline & $\mathrm{COM}+\mathrm{EV}+\mathrm{CRH}$ & 0,13 & 0,15 & 0,19 & 0,24 \\
\hline \multirow[t]{4}{*}{$\mathrm{pH}$} & $\mathrm{COM}$ & 4,88 & 5,33 & 5,61 & 5,86 \\
\hline & $\mathrm{COM}+\mathrm{EV}$ & 5,98 & 5,83 & 6,21 & 6,20 \\
\hline & $\mathrm{COM}+\mathrm{CRH}$ & 6,15 & 5,01 & 5,88 & 6,03 \\
\hline & $\mathrm{COM}+\mathrm{EV}+\mathrm{CRH}$ & 6,34 & 6,47 & 6,59 & 6,09 \\
\hline $\mathrm{EC}\left(\mathrm{mS} \mathrm{cm}^{-1}\right)$ & washed sand & 0,01 & 0,04 & 0,13 & 0,27 \\
\hline $\mathrm{pH}$ & washed sand & 6,02 & 7,23 & 7,14 & 7,13 \\
\hline TSS & washed sand & 0,04 & 0,16 & 0,47 & 0,68 \\
\hline
\end{tabular}

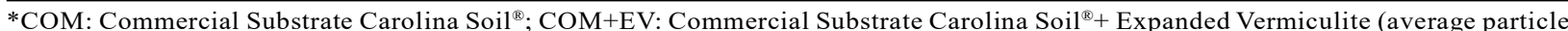
size); COM+CRH: Commercial Substrate Carolina Soil ${ }^{\circledR}+$ Carbonized Rice Hull; COM+EV+CRH: Commercial Substrate Carolina Soil ${ }^{\circledR}+$ Expanded Vermiculite (average paticle size) + Carbonized Rice Hull.

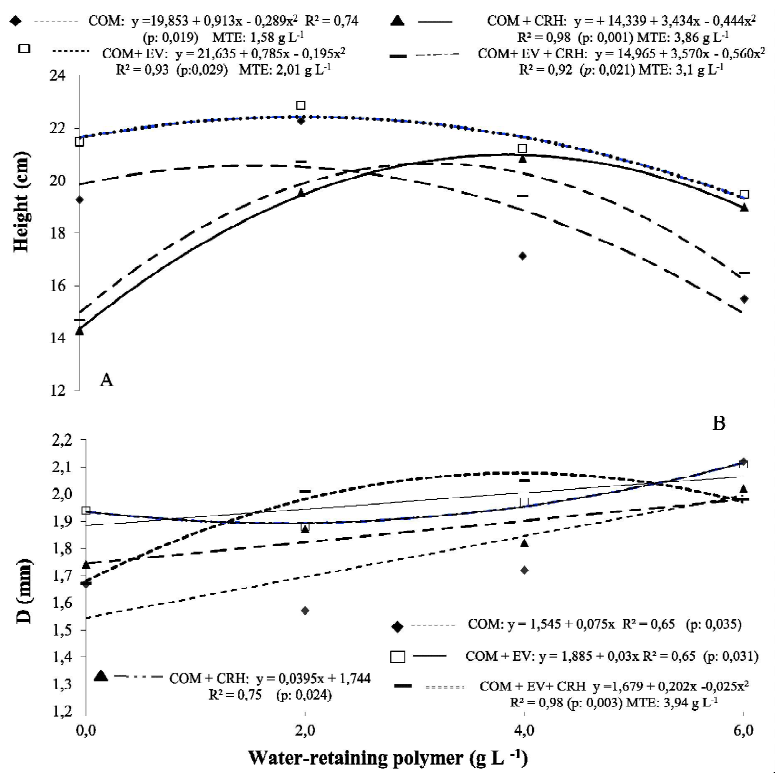

Figure 3 - A - Height (cm) and B - Neck diameter (D) of E. dunnii seedlings after 90 days of sowing by using different concentrations of natural polymer and different substrates.

Figura 3 -A - Altura (cm) e B-Diâmetro de colo (DC) das mudas de $\boldsymbol{E}$. dunnii utilizando diferentes doses do polímero vegetal e diferentes substratos, aos 90 dias após semeadura.

substrate mixture COM+EV (3.39 g) and the mixture of all three compounds ( $3.06 \mathrm{~g}$ ) have provided its highest values.

Revista Árvore, Viçosa-MG, v.40, n.4, p.627-637, 2016
E. dunnii seedlings have shown the highest SDM at a hydro polymer concentration of $3.38 \mathrm{~g} \mathrm{~L}^{-1}$ (Figure 4). The higher the biomass, the better the quality of seedlings, as the SDM represents both the leaf and the stem biomass, typifying the seedling's shoot structure able to perform photosynthesis and allocate carbon to the different parts of the plant.

\section{DISCUSSION}

According to the values indicated by Gonçalves and Poggiani (1996), which range from 75 to $85 \%$, most substrates were considered appropriate regarding total porosity (Figure 1A). However, according to De Boodt and Verdonck (1972), an ideal substrate must have a total porosity value of at least $85 \%$. Therefore, treatments composed by carbonized rice hull and addition of hydrogel are best featured for that matter.

Martyn and Szot (2001) have obtained a similar behavior for the porosity attribute when testing hydrogel concentrations with bark-based substrates. According to the authors, the total porosity obtained from the control substrate with no hydrogel added was lower (62.2\%) as compared to the other combinations, which provided higher values ranging from 80.5 to $83.9 \%$. Moreover, authors have noticed that the amount of micropores ranged from 4.2 to $6.7 \%$ so that higher concentrations of hydrogel have increased the percent of micropores as compared with the control substrate. 

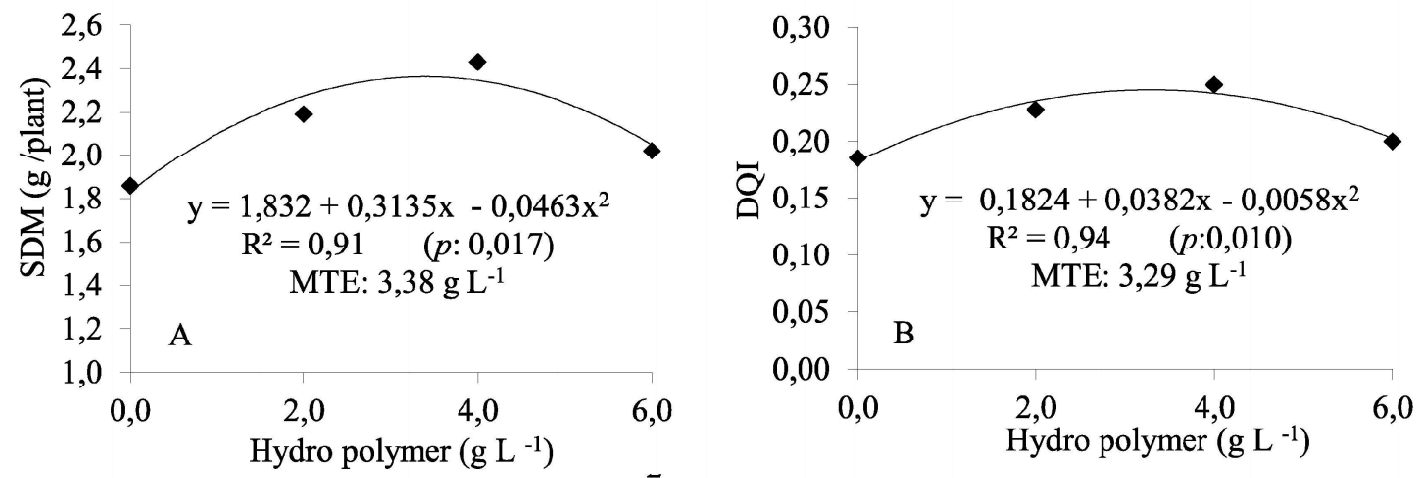

Figure 4 - A - Shoot dry matter (SDM) and B - Dickson Quality Index (DQI) of E. dunnii seedlings at different hydro polymer concentrations 90 days after sowing.

Figura 4 - A - Massa seca da parte aérea (MSPA); B - Índice de Qualidade de Dickson (IQD) de E. dunnii utilizando diferentes doses do polímero vegetal, aos 90 dias após semeadura.

Values obtained for the AS (\%), which is the difference between the total porosity and the volume of water retained at $10 \mathrm{hPa}$, are in accordance with what De Boodt and Verdonck (1992) considered to be ideal (20-30\%), even decreasing under higher concentrations of hydrogel, except for the commercial substrate, which has shown lower values when adding more than $4.0 \mathrm{~g} \mathrm{~L}^{-1}$ of natural polymer.

According to Abad et al. (1993), under optimal conditions the ideal substrate must provide from 24 to $40 \%$ of available water (AW) for plants and from 4 to $10 \%$ of water buffering capacity (WBC). Only the commercial substrate with hydrogel added at a concentration of 4.0 and $6.0 \mathrm{~g} \mathrm{~L}^{-1}$ has reached the minimum percent of these parameters. Same has happened with the readily available water (RAW) for which the recommended values range from 20 to $30 \%$ in accordance to Abad et al. (1993); Carrijo et al. (2002) and Fermino (2003).

Adding hydrogel causes the larger pores to be filled therefore decreasing the aeration space but increasing the water holding capacity. Water holding capacity is determined by the content, quantity and characteristics of the substrate components, especially organic matter and some types of inert material. Some materials such as vermiculite naturally retain a large amount of water which can substantially reduce the need of watering throughout the day (FERRARI, 2003). As Wendling and Gatto (2002) point out, the vermiculite has a high cation exchange capacity as well as water holding capacity, however, using pure vermiculite is not recommended because of its high cost and need for fertilizing frequently. Also, it does not allow the formation of a well-aggregated root system.

The commercial substrate has also shown a high water holding capacity so as to surpass the mixture of all three compounds. The carbonized rice hull mixing has shown the lowest water holding capacity among substrates. Several studies have demonstrated that carbonized rice hulls have a low water holding capacity and need constant watering, which makes them inconvenient for commercial farming purposes. The mixing type of substrates as well as the proportion of components of different groups must take into consideration the adjustment of physical properties, especially the water holding capacity, since chemical properties can generally be easily modified through fertilizing techniques and watering management (WENDLING; GATTO, 2002).

Water retention characteristic curves (Figure 2) demonstrate that hydrogels can act as water storage tanks in the substrate. The water retention characteristic curve of the substrate represents the relation between the volumetric water content and the matric potential, i.e., the force with which the substrate is holding the water, therefore providing information about the material's ability to retain and release water and giving an idea of the amount of water available to plants. Determining the water retention curve is important as it informs the amount of water available to plants within each matric potential range in a given sampling of substrate (SPIER et al., 2008).

Revista Árvore, Viçosa-MG, v.40, n.4, p.627-637, 2016

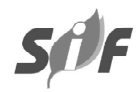


When the substrate has a low water holding capacity the water available to plants rapidly decreases, requiring more frequent watering. With a high water holding capacity the opposite occurs: the water available to plants is kept for longer which allows a larger watering interval. Hydrogels may thus support the water holding capacity so as to reduce watering amount or frequency especially during warmer periods with lower relative air humidity, when the evaporative demand increases. Furthermore, the water demand of the eucalyptus is very high as compared to other species so watering should be consequently increased. Knowing the water holding capacity is therefore important in order to allow a rational handling of plants according to the amount of available water.

Considering the parameters set by Gonçalves and Poggiani (1996) and Martinez (2002), the amount of retained water in pressures available to plants are featured above the ideal level, which ranges from 20 to $30 \%$ at $50 \mathrm{hPa}$, even when failing to use hydrogel in the substrate. However, upper values do not cause significant damage to the plant; one should manage watering so as to not waterlog the substrate, though.

The initial salinity of the substrate may affect the plants growth in which electrical conductivity levels above $3.5 \mathrm{mS} \mathrm{cm}^{-1}$ are considered excessive for most species (Martinez, 2002). Thus, all treatments among the substrates and hydrogel concentrations analyzed have values well below those considered as limit for the toxicity to occur. It should be remembered that the salinity found at the moment of the farming is higher than the one found in the analysis since the analysis of substrates were carried out only with the fertilizing contained in the commercial substrate. The highest EC obtained for the commercial substrate is therefore due to the fertilizing already incorporated into it. Accordingly, treatments with a lower proportion of commercial substrate $(\mathrm{COM}+\mathrm{EV}+\mathrm{CRH})$ have shown the lowest EC.

The corn starch-based polymer showed no variation pattern of $\mathrm{pH}$ related to its presence and/or concentration, especially for being a more neutral polymer (Table 1). Among substrates, mixtures containing CRH have shown the highest $\mathrm{pH}$.

Samplings of washed sand without hydrogel had practically no salts, however, after adding hydrogel their salt content has progressively increased in accordance with the polymer's concentration. Soluble salts have such characteristic because its concentration is highly influenced by the degree of hydration of the environment. However, even at the highest concentration of hydrogel the salt content is poor, being below the limit tolerated by most species including those most sensitive to salinity (KÄMPF, 2005). Due to the sand's low CEC and hence its low $\mathrm{pH}$ buffering capacity such changes are not important since mixing hydrogel to the substrates caused a much inferior change (Table 1).

Regarding seedlings height, hydrogel concentrations have shown good results mainly in substrates that naturally retain less water, such as occurred to the $\mathrm{COM}+\mathrm{CRH}$ mixture. High concentrations of hydrogel ended up by inducing a lower seedling height as compared to the lowest concentration of hydrogel or the failure to use it. Such result may be related to the fact that the commercial substrate already has a high water holding capacity. In this case, the further increase in the WHC caused by adding high concentrations of hydrogel might have caused an excessive accumulation of water on the root system therefore impairing the growth of seedling height, which might be indirectly related to a low nutrient absorption by plants.

Rice hull is used due to its low cost, however, as a substrate component for forest seedlings it often faces the low availability of nutrients and high leaching. According to our results, adding hydrogel to it could be a feasible alternative to improve its physical characteristics therefore increasing the final quality of seedlings. Since the commercial substrate mixed with expanded vermiculite has shown a high water holding capacity the results thus indicate that for substrates containing these components (COM+EV) one can add lower concentrations of hydrogel $\left(2 \mathrm{~g} \mathrm{~L}^{-1}\right)$. Results obtained from the physical analysis of the substrate have reflected on the seedling morphological features by reducing its height when increasing the concentrations of hydrogel or the use of COM+EV as substrate. Same has happened to the variable D which slightly increased at the highest concentration of hydrogel.

According to Gonçalves et al. (2005), substrates with high WHC require a stricter watering control in order to avoid waterlogged substrates - what has probably occurred at the highest concentrations of 
the water-retaining polymer. Yet substrates with higher WHC normally have lower losses by nutrients leaching and may thus produce plants with a higher height and neck diameter (HUETT; MORRIS, 1999). To prevent the excess of water in the root zone there is a need for adjusting both the watering frequency and the water blade. Excess of soil or substrate moisture might cause stress to the plants and therefore a lack of oxygen to the root zone (TAIZ; ZEIGER, 2009).

Mixing commercial substrate with more porous components, such as vermiculite and carbonized rice hull, has enabled a better rooting, as verified by the highest RDM, which can be especially beneficial at field planting time. According to Almeida et al. (2005), a higher root biomass provides a better performance of seedling at field since its survival probability increases due to its greater ease of support and greater area for absorbing water and nutrients.

Using the water-retaining gel especially at a concentration of $3.29 \mathrm{~g} \mathrm{~L}^{-1}$, as verified by the quadratic regression equation, has provided seedlings with upper Dickson quality indexes, which features higher values of neck diameter, shoot dry matter, root dry matter and total dry matter; and lower values of shoot: root ratio and $\mathrm{H} / \mathrm{D}$ ratio therefore showing a good indication of seedlings quality when making use of the hydro polymer, especially at suitable concentrations (Figure 4B).

For the majority of variables under analysis, especially height, neck diameter, SDM and DQI, using hydrogel at up to certain concentrations is beneficial to the quality of seedlings. Azevedo et al. (2002) and Peterson (2003) corroborate it by concluding that adding hydrogel optimizes the availability of water, reduces losses by percolation and leaching of nutrients, and improves the soil (or substrate) drainage and aeration therefore accelerating the shoot development of seedlings. Zonta et al. (2009) reported that increasing water absorption and retention through hydrogel makes the water more readily available to the plant thus allowing a better development. Our study corroborates it by indicating that the presence of water-retaining polymer has significantly increased the percent of water retained in the ranges available to plants, i.e., readily available water and water buffering capacity (up to $-100 \mathrm{hPa}$ ). Similarly, the slight increase observed in the percent of soil water retention for treatments with the presence of water-retaining polymer has also contributed to the maintenance of seedlings under water stress conditions.

\section{CONCLUSION}

Adding water-retaining polymer to substrates improves their chemical and physical properties, especially those relating to porosity, available water and water holding capacity.

Carbonized rice hull as a substrate mixing component increases the development of physical characteristics as well as the seedlings growth, especially if combined with the addition of hydrogel.

\section{REFERENCES}

ABAD, M.; MARTINEZ, P.F.; MARTINEZ, J.

Evaluación agrónomica de los substratos de cultivo. Actas de Horticultura, v.11, p.141-154, 1993.

ALMEIDA, L.S.; MAIA, N.; ORTEGA, A.R.; ANGELO, A.C. Crescimento de mudas de Jacaranda puberula Cham. em viveiro submetidas a diferentes níveis de luminosidade. Ciência Florestal, v.15, n.3, p.323-329,. 2005.

AZEVEDO, T.L.F.; BERTONHA, A.; GONÇALVES, A.C.A. Uso de Hidrogel na agricultura. Revista do Programa de Ciências AgroAmbientais, v.1, n.1, p.23-31, 2002.

BERNARDI, M. R.; SPEROTTO JUNIOR, M.; DANIEL, O.; VITORINO, A.C.T. Crescimento de mudas de Corymbia citriodora em função do uso de hidrogel e adubação. Cerne, v.18, n.1, p.67-74, 2012.

BRASIL. Ministério da Agricultura, Pecuária e Abastecimento. Instrução Normativa SDA No 17. Diário Oficial da União- Seção 1, nº 99, 24 de maio de 2007. Métodos Analíticos Oficiais para Análise de Substratos para Plantas e

Condicionadores de Solo. Brasília: 2007.

CALDEIRA, M.V.W.; MARCOLIN, M.; MORAES, E.; SCHAADT, S.S. Influência do resíduo da indústria do algodão na formulação de substrato para produção de Schinus terebinthifolius Raddi, Archontophoenix alexandrae Wendl. et Drude e Archontophoenix cunninghamiana Wendl. et Drude. Revista Ambiência, v.3, p.311-323, 2007.

CARRIJO, O.A.; MAKISHIMA, N.; LIZ RS. Fibra da casca de coco verde como substrato agrícola. 
Horticultura Brasileira, v.20, p.533-535, 2002.

DE BOODT, M.; VERDONCK, O. The physical properties of the substrates in horticulture. Acta Horticulturae, v.26, p.37-44, 1972.

DICKSON, A., LEAF, A.L.; HOSNER, J.F. Quality appraisal of white spruce and white pine seedling stock in nurseries. Forest Chronicle, v.36, p.10-13, 1960.

FERMINO, M.H. Métodos de análise para caracterização de física de substratos. 2003. 89f. Tese (Doutorado em Fitotecnia) Universidade Federal do Rio Grande do Sul, Porto Alegre, 2003.

FERRARI, M.P. Cultivo do Eucalipto: Produção de mudas. Versão Eletrônica. 2003. (Sistemas de Produção 4) Disponível em: http:// sistemasdeproducao.cnptia.embrapa.br/ FontesHTML/Eucalipto/CultivodoEucalipto/ 03 producao_de_mudas.htm. Acesso em: $16 \mathrm{de}$ set. 2012 .

FERREIRA, D.F. SISVAR: a computer statistical analysis system. Ciência e Agrotecnologia v.35, n.6, p.1039-1042, 2011.

GONÇALVES, J.L.M.; POGGIANI, F. Substrato para produção de mudas. (Compact disc). In: SOLO SUELO - CONGRESSO LATINO AMERICANO DE CIÊNCIA DO SOLO, 13., Águas de Lindóia, 1996. Anais... Águas de Lidóia: SLCS; SBCS; ESALQ/USP, CEA; SBM, 1996.

GONÇALVES, J.L.M.; SANTARELLI, E.G.; MORAES, S.P.; MANARA, M.P. Produção de mudas de espécies nativas: substrato, nutrição, sombreamento e fertilização. In: GONÇALVES, J.L.M.; BENEDETTI, V. (Ed.). Nutrição e fertilização florestal. Piracicaba: IPEF, 2005. p.309-350.

HUETT, D.O.; MORRIS, S.C. Fertiliser use efficiency by containerised nursery plants. Effect of heavy leaching and damaged fertiliser prills on plant growth, nutrient uptake, and nutrient loss. Australian Journal of Agriculture Research, v.50, n.2, p.217-222, 1999.

INSTITUTO NACIONAL DE METEOROLOGIA INMET. Banco de Dados Meteorológicos

Revista Árvore, Viçosa-MG, v.40, n.4, p.627-637, 2016 para Ensino e Pesquisa. Disponível em: http://www.inmet.gov.br/projetos/rede/pesquisa/ form_mapas_mensal.php. Acesso em: 21 de ago de 2013 .

KÄMPF，A.N. Produção comercial de plantas ornamentais. 2.ed. Guaíba: Agrolivros, 2005. 256p.

MARTÍNEZ, P.F. Manejo de substratos para horticultura. In: FURLANI, A.M.C.; BATAGLIA, O.C.; ABREU, M.F.; ABREU, C.A.; FURLANI, P.R.; QUAGGIO, J.A.; MINAMI, K.

Caracterização, manejo e qualidade de substratos para a produção de plantas. Campinas: Instituto Agronômico de Campinas, 2002. p.53-76.

MARTYN, W.; SZOT, P. Influence of superabsorbents on the physical properties of horticultural substrates. International Agrophysics, v. 15, p.87-94, 2001.

MORENO, J.A. Clima do Rio Grande do Sul. Porto Alegre: Secretaria da Agricultura, 1961. $83 p$.

PETERSON, D. Hydrophilic polymers: effects and uses in the landscape. Soviet Soil Science, v.13, n.4, p.111-115, 2003.

RÖBER, R.; SCHALLER, K. Pflanzenernährung im Gartenbau. Stuttgart: Ulmer, 1985. 352p.

SPIER, M.; SILVA, D.S.; SCHÄFER, G.; SOUZA, P. V. D. Obtenção da curva de retenção de água pelo método da pressão positiva. In: ENCONTRO NACIONAL SOBRE SUBSTRATO PARA PLANTAS, 6.,Fortaleza. Resumo expandido... Fortaleza: Embrapa/CNPAT, 2008. v.1.

TAIZ, L.; ZEIGER, E. Fisiologia vegetal. 4. ed. Porto Alegre: Artmed, 2009. 848p.

TAYLOR, K.C.; HALFACRE, R.G. The effect of hydrophilic polymer on media water retention and nutrient availability to Ligustrum lucidum.

Horticulture Science, v.21, p.1159-1161, 1986.

WENDLING, I.; GATTO, A. Substratos, adubação e irrigação na produção de 
mudas.Viçosa, MG: Aprenda Fácil, 2002.

ZONTA, J.H.; BRAUN, H.; REIS, E.F.; AULUCIO, D.; ZONTA, J.B. Influência de diferentes turnos de rega e doses de hidroabsorvente no desenvolvimento inicial da cultura do café conillon (Coffea canephora Pierre). Idesia, v.27, n.3, p.29-34, 2009. 